\title{
Brexit, Boundaries, and Imperial Identities: a comparative view
}

Final draft submitted to the Journal of Social Archaeology

\author{
Author: \\ Dr Andrew Gardner \\ UCL Institute of Archaeology \\ 31-34 Gordon Square \\ London \\ WC1H OPY \\ United Kingdom \\ +44 (0)20 76794740 \\ andrew.gardner@ucl.ac.uk
}

\section{Biographical note}

Andrew Gardner is Senior Lecturer in the Archaeology of the Roman Empire at the UCL Institute of Archaeology. His publications include An Archaeology of Identity: Soldiers and Society in Late Roman Britain (2007) and Evolutionary and Interpretive Archaeologies: a Dialogue (edited with Ethan Cochrane, 2011); he is currently working on a monograph on Roman Britain. His research interests are centred upon the social dynamics of Roman imperialism, the role of material culture in the creation of identity, and the ways in which people in different societies understand time.

\begin{abstract}
2016 will be marked as a year in which identity politics reached new levels of significance. Among numerous dramatic events, the UK referendum on membership of the European Union has brought many issues of interest to archaeologists to the fore. These range from entirely contemporary concerns such as the future of research funding in Britain to topics of more longitudinal significance, including the interactions between different identity groups in particular economic and political circumstances. In this paper, I wish to explore aspects of the distinctive position of Britain as an illustration of identity dynamics in the long-term, focussing on the relationship between imperialism and identities, and viewed through the lens of recent work in Border Studies. Brexit can be seen as the culmination of the collapse of the British empire, and British identity, in the post-WWII era and the particular dynamics of this process invite comparison with Britain's earlier position as one of the frontier provinces of the Roman empire, especially in the $4^{\text {th }}$ and $5^{\text {th }}$ centuries AD. This comparison reveals two paradoxical dimensions of imperial identities, the first being that so-called 'peripheries' can be more important than 'cores' in the creation of imperial identities, and the second that such identities can be simultaneously ideologically powerful yet practically fragile in the circumstances which follow imperial collapse. Such insights are important because, at a time of apparently resurgent nationalism in many countries, archaeologists need to work harder than ever to understand identity dynamics with the benefit of time-depth.
\end{abstract}

\section{Keywords}

Imperialism, identities, border-thinking, European Union, Britishness, Roman archaeology 


\section{Introduction: archaeology and identity in the new age of populism}

The extraordinary events surrounding the UK's referendum on European Union membership in late June, 2016, seem to be part of a series of current political stories in which status quo situations are being challenged, conventions of public discourse broken, and ideas of progress in global integration overturned. Hindsight will judge how significant these events really are, but they also demand an immediate response from the academic community, both as scholars and as citizens, and from archaeologists as much as anyone else. This is because some of the trends appearing to manifest themselves in these events directly concern the relationships between identity groupings and ideas of shared or divergent pasts (and futures) that archaeologists have been interested in for some time. The lessons of many such studies, moreover, highlight how in previous moments of prominent nationalist and populist political discourse, archaeologists have sometimes become directly embroiled, if not actively culpable, in buttressing some of the spurious claims to historical legitimacy of such movements (Arnold 1990; Díaz-Andreu 2007; Meskell 2002). This time we can be better prepared (cf. e.g. Gustafsson and Karlsson 2011). Many analyses of the circumstances leading up to the 'Brexit' vote, its implications, and the similarities it bears to events such as the US election result, will be written across many media in the coming months and years. This paper is intended to contribute one long-term view to understanding some aspects of the referendum result and highlighting comparisons between this situation and earlier historical contexts. Specifically, my aim is to explore the dynamics of identities in imperial situations, and I will argue that there are instructive comparisons between the processes underway in the later and post-Roman empire, in the $4^{\text {th }}$ and $5^{\text {th }}$ centuries $\mathrm{AD}$, and the fate of the British empire in the $20^{\text {th }}$, the latter context being crucial to the 'Brexit' story. This comparative exercise yields insights into the relationships between frontiers, empires and identities which will hopefully be of value in understanding both past situations of this sort and some of the present political crises; it will also highlight some of the distinctive dynamics of 'Brexit' compared to other manifestations of contemporary populism. To be clear, while I voted for Britain to remain in the EU in the referendum and have strong opinions about its outcome, the objective of this paper is less to be politically activist in the sense advocated by Tilley (1989) or McGuire (2008) - valid though that standpoint is - or to be judgemental of those with different views, and more to seek understanding of why this event has happened and glean some critical insight from it. Some further thoughts on the relationship between the personal, the political and the scholarly are offered in the conclusion.

Before delving into the imperial context of Brexit and its possible comparative value, a little background to the events (so far) is necessary. A commitment to hold an 'in/out' referendum on UK membership of the European Union was made in the Conservative party manifesto for the May 2015 general election. When that election resulted in a surprise Conservative majority in the House of Commons, the road to a referendum was taken fairly swiftly, with the legislation to establish the terms of the plebiscite drafted and passed by parliament by $17^{\text {th }}$ December 2015, at the same time as Prime Minister David Cameron and others pursued a campaign of international diplomacy in an attempt to secure more preferable terms of British membership. When this concluded in February 2016 the referendum date was fixed and campaigning began in earnest, though the official campaign period only began on $15^{\text {th }}$ April, and the vote took place on $23^{\text {rd }}$ June (BBC 2016a; Electoral Commission 2016; Parliament 2015). Approximately 33.5 million people voted, $72 \%$ of the eligible electorate. $52 \%$ voted to leave the EU and $48 \%$ to remain, a difference of nearly 1.3 million votes (BBC 2016b). The result took many politicians and commentators by surprise and in its aftermath there have been dramatic party political changes including the appointment of a new Prime Minister, and widespread disagreements about the meaning of the result and its various impacts, though these certainly include a rise in reported hate-crimes against immigrants (by 
41\%, comparing July 2016 to July 2015; BBC 2016c), and not just those of EU origin who had been targeted by some elements in the 'leave' campaign. A range of petitions, social media groupings and other responses have appeared to represent 'remain' voters, including a new newspaper (The New European), while an equally wide range of approaches to negotiating Brexit have appeared among the 'leave' camp.

This is not the place to go into all of these still-developing aspects of the referendum result. More pertinent are a couple of themes which provide the immediate context for the vote. One of these is of course the trajectory of Euroscepticism in British politics that goes back to the UK's troubled early relationship with the forerunner to the EU, the EEC (European Economic Community), which Britain initially declined to participate in at its foundation in 1957, then was excluded from through the 1960s, but finally joined in 1973, with a referendum in 1975 to ratify that decision (Wilson 2014). Sections of both the Labour and Conservative parties have remained ambivalent or hostile to European integration ever since, while explicitly anti-EU parties - particularly the Referendum Party and its successor UKIP (UK Independence Party) - have steadily grown since the mid-1990s, initially in response to the Maastricht Treaty of 1992 which formalised the transition from the EEC to the EU, and then to currency union which took place across much of Europe from 1999 (BBC 2015). Such sentiments have also been dominant in significant sections of the print news media over the same period (see e.g. Barnett 2016; Martinson 2016). A second important theme is the political geography of the UK, which has not remained static in recent decades. Devolution of powers from the London-based UK government to Scotland, Wales and Northern Ireland - the latter in the context of the peace agreement to end the 'Troubles' have been a significant development since the late 1990s, with Scotland perhaps most prominently following this pathway to the point of having a referendum on full independence in 2014; this resulted in a vote for continued union by $55 \%$ to $45 \%$ (BBC 2014a; cf. Colley 2007). These changes have in turn led to a focus on the question of English identity, in legislative, cultural and academic contexts (BBC 2013; BBC 2016d; Preston 2004). These centrifugal trends in the 'United' Kingdom appear to have been reinforced in the vote on $23^{\text {rd }}$ June, and this is a key theme that many commentators have focussed on (along with generational, educational, and economic divides), with Scotland, Northern Ireland, and London (plus its commuter belt and some other big cities) trending 'remain', and much of England and Wales voting 'leave' (BBC 2016e; Taylor 2016; cf. Flip Chart Fairy Tales 2016). Taken together, these issues to do with the equivocal international outlook of Britain since the Second World War, and the balance of British vs. other national identities within the UK, provide crucial context for understanding the referendum result. They also offer inroads to explore further back in time in search of a deeper understanding, particularly in relation to the dynamics of empire and what comes after, for both have a post-colonial dimension, as will be explored further below.

This point does, though, prompt the questions, what does all of this have to do with archaeology, and what can archaeologists meaningfully contribute to the debates these events have opened up? Clearly there are very practical intersections with the future fortunes of archaeologists, in whatever context they work, in relation to funding for university research, or other economic impacts upon the construction industry, for example. There are also ideological consequences for the direction of travel of the whole of UK academia, which may in turn impact on staff and student recruitment, ease of working internationally and so on (see e.g. Gill 2016). Two intersections stand out, though, between these events and our discipline. The first is the role of received ideas about the past in influencing people's feelings about their identity in the present, and thus their political decisions. This is a well-researched area which has furnished us with numerous case-studies of the archaeological contribution to national, colonial, post-colonial and other cultural identities in modern times and across the 
globe (e.g. Atkinson et al. (eds) 1996; Colwell-Chanthaphonh 2012; Gosden 2012; Hingley 2015; Kohl and Fawcett (eds) 1995; Meskell (ed.) 1998; 2002; Trigger 1984). Such studies have highlighted both the frequent political manipulation of interpretations of the past, as well as some of the positive effects of using heritage in community-building and progressive political activism. It seems clear that, if Britain and indeed Europe and the US are facing a resurgence of nationalist political trends, we need to be highly alert to this unfolding situation and apply the lessons learned from this work accordingly, particularly through developing prompt critical responses (cf. Green (ed.) 2016; Gustafsson and Karlsson 2011; Williams 2016). The second area of intersection lies in the broader role of archaeology to use its longterm, comparative perspective - without sacrificing depth of understanding of particular cultures - to inform wider discussion of social theoretical concepts which are at play in these current events. In this case, the specific domain of identity - how it works as a process, how identity-concepts vary across time and space, and how people become mobilised by particular identities - is obviously crucial. Archaeological discussion of identity is of course very wellestablished (e.g. Díaz-Andreu et al. (eds) 2005; Gardner 2007; Hales and Hodos (eds) 2010; Jones 1997; Meskell 1999; 2001; Shennan (ed.) 1989), and has perhaps recently entered a more critical phase where the utility of the concept has been questioned from different standpoints (e.g. Casella and Fowler 2005; Pitts 2007; cf. Harris 2016). It is my contention in this paper that recent events highlight the value of much of the archaeological discussion of identity in the 1990s and early 2000s, and that there is considerable pragmatic benefit to be gained from continuing to pursue some of the ideas developed during that period. I will expand upon this theoretical component of my argument in the central part of this paper, in the context of recent work in the field of 'Border Studies', but before reaching that point a discussion of 'British' identities will help lay the groundwork, by illustrating some of the key processes.

\section{'Britishness' and Brexit: the long view}

In seeking to analyse the formation and dissolution of imperial identities as part of the context of Brexit, a critical history of 'Britishness' is essential, though of course it can only be dealt with in broad-brush terms in this paper. This history essentially begins with the Romans. Even though much would be made in later centuries of the 'Celtic' identities of the pre-Roman inhabitants of Britain and Ireland, there is little evidence that people in these areas at the time of contact with Rome adhered to any such broad cultural grouping (Collis 2003; James 1999). It rather seems to be the case that, as in other imperial and colonial situations elsewhere in the world at different times, loose 'tribal' groupings crystallized as part of the contact process and then became more fixed in those areas that came under Roman rule, encompassing what is now England and Wales (e.g. Creighton 2000; Hill 2007; Moore 2011; cf. e.g. Derks and Roymans 2009; Ferguson and Whitehead (eds) 2000; Gardner et al. (eds) 2013). Above this scale of identity sat 'Britishness', similarly an artefact of the imperial process, and like some of the regional identities apparently becoming internalized over time (Matthews 1999; cf. Jenkins 2000; 2014 on the identity processes underlying this, based especially on Goffman 1990 [1959]). 'Native' people within the Roman province(s) of Britain might therefore have identified as Britons, Romans (if they were citizens, as most were by the $3^{\text {rd }}$ century AD) and/or members of a regional grouping, such as one of the later Roman provinces or more likely the smaller administrative units, the civitates in the Roman system, such as the Catuvellauni or the Silures (Dark 1994; White 2007). Those outside the Roman-controlled territory, in what became Scotland and Ireland, would have had less direct experience of colonially-administered identities, but there are also signs of more cohesive groupings forming over time, such as the Picts in the north (Hunter 2007). While we might also expect resistant or discrepant identities within the Roman provinces (cf. Given 2004; 
Mattingly 2004; 2006), these are more challenging to locate. More clearly, there is actually evidence for the continuation of both 'British' and 'tribal' identities after the end of Roman administration in the early $5^{\text {th }}$ century, particularly from some of the small number of insular written sources, such as inscribed stones (White 2007: 154-76; 202-7), and the $5^{\text {th }} / 6^{\text {th }}$ century writings of Patrick and Gildas. It is especially notable that both of these authors appear to have abandoned the idea of being Roman (even though they write in Latin), but do identify as Britons (Higham 2002: 39-73; Jones 1996: 121-30). This is suggestive of the fragility of a transcendent imperial/civic identity compared to smaller-scale ethnicities in a post-colonial context (cf. Gardner In Press; Geary 2002: 104-8; Higham 2002: 45-6). This process, explored in more detail in the second half of this paper, is highly relevant to 'Britishness' in the $20^{\text {th }}$ and $21^{\text {st }}$ centuries, and in turn to Brexit.

Another layer of identities was soon introduced to the post-colonial 'British' world of the early Medieval period, in the form of the various groups subsequently labelled 'AngloSaxons'. As with the origins of 'Celtic' Britain, there is academic and popular controversy over the scale and nature of the migration of people from northern Germany and southern Scandinavia to eastern Britain (see e.g. Hills 2003; 2011), but this need not concern us here. The key point is that by the $8^{\text {th }}$ and $9^{\text {th }}$ centuries a state was forming that was defined as distinctively English, and the Venerable Bede wrote its history at this time as one of conflict with the Britons. This construct of a division between the English and the Britons would undoubtedly have had an effect on the latter identity too, which may be evident in the archaeology of this period in the west and north (Higham 2002: 59-73, 98-102). Even more crucial to the later history of Britishness, though, is what happened next, as that English state, particularly under the Anglo-Norman kings of the $11^{\text {th }}-13^{\text {th }}$ centuries, embarked upon the first stage in the eventual formation of the British empire, which was the creation of an English empire across Wales, Scotland and Ireland. In the process of doing so, these monarchs, aided by some of those who created histories and other representations of the period, combined military conquest with cultural appropriation. For example, from the 'discovery' and reburial of the purported remains of Arthur and Guinevere in 1191, to the efforts of Edward I to seize Arthurian relics in the 1280s, right through in fact to the Arthurian pageants of Elizabeth I in the $16^{\text {th }}$ century, English monarchs sought to suppress non-English identities through the elimination and/or co-option of British folk figures like King Arthur (Davies 2000: 31-53; Higham 2002: 218-35; cf. Gardner 2011; Paphitis 2014; White 2007: 209-14). As a result, the label 'British' - which had hitherto come to be used particularly by the Welsh to distinguish themselves from the English - was over-written by English power in a nascent English empire (Davies 2000: 31-53). The erasure of the ethnic meaning of Britishness, and the appropriation of some of its key symbols by the English state, meant that after the formal unions of the crowns and then the kingdoms of England, Wales, Scotland and Ireland during the $16^{\text {th }}-18^{\text {th }}$ centuries, 'British' identity was free to be taken as the new imperial identity of the now 'United Kingdom', and was also suited to exporting further around the world. Importantly, though, some of the ethnic divisions at home concealed by this new identity were then re-created through the 'discovery' of 'Celtic' heritage for those parts of Britain and Ireland that saw themselves as non-English, effectively perpetuating the symbolic content of the previous notion of 'Britishness' (Colls 2002: 34-49, 275-88; James 1999: 43-66; Kidd 1999: 83-98, 185-93). This latter term would, though, go on to develop a different trajectory in its wider imperial context.

The crucial period for the coalescence of this new version of British identity was the $18^{\text {th }}$ and $19^{\text {th }}$ centuries, following the 1707 Act of Union which created 'Great' Britain, and it gained a particular character influenced by developments such as industrialisation and the American revolution. The latter was particularly important in terms of imperial identities as marking a break between the early colonies associated more firmly with the 'English' empire 
and the later colonies in Africa, India and elsewhere that came to play a defining role in 'British' imperialism (Edmunds 2004: 74-5; Ward 2004: 243-5). How 'Britishness' came to be constructed in the ensuing period up to the $20^{\text {th }}$ century is of course a complex story for which space is not available here. The most important point for my argument, though, is that this dynamic identity category had both exclusive and inclusive characteristics, and that while among the former were developing theories of race, particularly in the $19^{\text {th }}$ century, the latter were prominent in the absorption of certain symbols and practices from both the 'internal' (Scottish, Welsh, Irish) and external (particularly Indian and Chinese) edges of empire (Alibhai-Brown 2016; Hechter 1975; Ichijo 2004; Lawrence 2003). A key point of this paper is that this duality of essentialism and hybridity is a crucial part of identity processes in imperial contexts. While a variant of all processes of identity - necessarily involving a dialogue between similarity and difference (Jenkins 2014; cf. Gardner 2011) - there are particular aspects of the interaction between imperial and subaltern actors that give this dynamic a characteristic shape. Partly, of course, these involve imperial violence, something still controversial in the British case but increasingly being brought to light (e.g. Parry 2016), and inevitably a formative influence on the identities of both colonisers and colonised (Colley 1992). This is one part, but not the only part, of the interaction between 'core' and 'peripheral' identities. It is notable that the highpoint of ideological work by the state to create a strong British imperial identity occurred in the later $19^{\text {th }}$ and early $20^{\text {th }}$ centuries, a period when various crises - from the Indian Mutiny in 1857, through the Boer Wars at the end of the $19^{\text {th }}$ century, and up to the First World War - highlighted threats to the empire both within specific territories and from European competitors. While in some sense the new 'Britishness' was thus a nationalist identity, and in some contexts synonymous with 'Englishness', this idea was also successfully exported across the empire, perhaps partly because it was simultaneously a hybrid identity, symbolised by practices derived from colonial contexts, like tea-drinking (Alibhai-Brown 2016: 143-65; Hall 2008; Lawrence 2003; cf. Porter 2004; Young 2008). Even as this empire came relatively rapidly to an end in the mid- $20^{\text {th }}$ century, with independence movements coming to a head in the aftermath of the Second World War, many people in former colonies retained a British identity, and much of the post-War migration to the UK from the Caribbean, Africa and South Asia was by people for whom this was a prominent connection. Indeed, it was one entirely encouraged by the British state in the early 1940s and '50s, but significantly curtailed in the 1960s (Ward 2004: 245-58).

This is actually an important part of the context for Brexit, and not just in relation to some of the unedifying attitudes to immigration which characterised the 'leave' campaign and which are often traced back to the 1960s (though, of course, these are another feature of earlier British imperial history too; Colley 1992: 317). My contention is that the relationship of 'British' identity to Brexit has significant implications for other imperial contexts, so this relationship needs careful unpacking. So far we have seen how a British (ethnic) identity born out of Roman imperialism was subordinated to English imperialism, and largely divested of ethnic significance, allowing it to then be re-invented as a more hybrid imperial identity which could unite people in the British Isles and beyond. While at certain points in the later $19^{\text {th }}$ and $20^{\text {th }}$ centuries it came too to have more ethnic significance in the UK, this has retreated in the post-imperial period. As an imperial, encompassing identity, defined by a mixture of symbols drawn from disparate parts of the empire, it seems to have lost currency in parts of the UK itself in the later $20^{\text {th }}$ and early $21^{\text {st }}$ centuries. This is evident from the census data gathered in 2011, which shows that 'English' and other sub-UK national identities are gaining in popularity over 'Britishness', though the latter remains more important among the (overlapping) categories of city-dwellers, younger people, and people with Afro-Caribbean or Asian backgrounds (Easton 2013; cf. Edmunds 2004: 79-82; Madood 
2004). Comparing the distribution of the areas with the strongest adherence to the "home nation' identities with the concentrations of 'leave' voters in the referendum (BBC 2016e) is quite instructive. The correspondence is not absolute, as there are different processes at work here, but I suggest that many of these are legacies of empire, whether in terms of the identitypolitics discussed in this paper, or economic inequalities arising from globalisation, which were of course another major factor in the referendum. Scottish self-identity is strong, and arguably this is an example of how a national self-identity can be formed from a colonial one, with many of the archetypal symbols of Scottishness being crafted in the context of EnglishScottish relations in the $18^{\text {th }}$ and $19^{\text {th }}$ centuries (Ichijo 2004; Trevor-Roper 1983), and subsequently reinforced also by diaspora communities. This identity is not incompatible with EU sympathies, though, perhaps because it is relatively self-confident and sees commonalities with other small nations that have prospered within the EU; Northern Ireland is somewhat similar. In England and Wales, however, rejection of Britishness goes together with EU-scepticism in many areas, and particularly eastern England (Fig. 1). In Wales, the former could be a reflection of anti-English sentiment (as in Scotland, see e.g. BBC 2014b), but across both countries it seems that - as the founding union of the United Kingdom from the $1530 \mathrm{~s}$ - these two regions were for so long the 'core' of the British empire that they have faced the biggest identity crisis since the collapse of that empire. Many voters in these regions apparently blame the EU for the erosion of their identity, but it seems more likely from the foregoing that this is actually the consequence of imperial processes (cf. Colley 2007; Kearney 1991; Ward 2004; Yeandle 2004: 286). Over the long-term, 'Britishness' came to be something defined as much from the periphery as the centre. The demise of the empire, combined perhaps with a failure to really deal with its legacy (reflected even since the vote in various positive references to that era; Andrews 2016), has created an identityvacuum in what was, 500 years ago, the place where it all began. Brexit thus appears to be, at least in part, the latest symptom of the resurgence of pre-British (imperial) identities which are closer to the ancient British (ethnic) identity in form - i.e. it is a post-colonial process in the heart of empire. To understand this complex situation more clearly, and consider further how it might be paralleled in antiquity, we now need to consider briefly recent developments in the theory of borders and frontiers, and their relationship to identity-formation.

\section{Frontiers, boundaries and imperial identities - in theory}

'Border Studies' is a relatively new interdisciplinary field drawing upon deeper traditions of enquiry into the nature of frontiers and boundaries. Encompassing the work of scholars in Anthropology, Sociology, International Relations and other areas, this programme has arisen largely out of the realisation that far from generating an entirely 'liquid' world, globalisation has actually led to a renewed phase of national and regional identity formations, or 'reterritorialization' (Bude and Dürrschmidt 2010; Mezzadra and Neilson 2013: ix, 1-4; Newman 2006). Indeed, these processes must of course be seen as complementary, in a manner already alluded to - hybridity creates essentialism and vice versa in matters of identity (Jenkins 2014: 20-7, 151-8; Mezzadra and Neilson 2013: 1-25; Rumford 2006). Themes pursued under the Border Studies banner include many contemporary concerns - the new security apparatus of borders (especially since 9/11), or the interwoven issues of citizenship, migration, and labour - and there are a number of different takes on the precise terminology of borders, boundaries and frontiers (Jenkins 2015; Mezzadra and Neilson 2013: 14-9). A common focus, though, and one which is perhaps exaggerated in, but need not be confined to, modernity is an emphasis on borders as not simply geographical constructs, but as subjective ones which permeate social interactions of all kinds. Moreover, there is considerable attention to the colonial and post-colonial aspects of bordering at both ontological and epistemological levels - that is, in terms of the particular subjectivities of 
people for whom colonial bordering is consequential (whether as hybrid identities or 'double consciousness', or indeed considered as part of the colonisers' experience), and also the implications for a discipline's relationship to its object (Alvarez 1995; Kearney 1991; Mignolo and Tlostanova 2006). This perspective is evident in some of the anthropological case studies from which a number of scholars have drawn, particularly in the vicinity of the US/Mexico border (e.g. Alvarez 1995), and creates a contrast with some of the more positivist globalization theories with which archaeologists are increasingly engaged (Krishnaswamy 2007: 2; cf. Gardner 2013: 3-9). The outcome of this is a programme of work driven by 'border thinking', seeking to articulate the heterogeneous bordering practices of everyday life which define people as similar or different to each other, and thus both manifest and transform not only identity groupings, but also power relationships (Cooper and Perkins 2011; Parker and Vaughan-Williams 2009; Rumford 2006). Placing bordering at the heart of social life clearly makes this move relevant to archaeology.

Indeed, one could argue that such a programme is quite well-developed in archaeology, within which a range of studies of frontiers and boundaries (e.g. Lightfoot and Martinez 1995; Stark (ed.) 1998), and of colonial experiences (e.g. Cusick (ed.) 1998; Lightfoot et al. 1998; Stein (ed.) 2005), have moved well beyond simplistic historicalgeographical, functionalist, or world-systems approaches to borders (to use the classification of Kolossov 2005). However, what the 'border thinking' programme does is to give us a holistic view of both the centrality of boundaries and boundary-crossing to all human sociality, and the specificity of different constructs of boundedness. This means it provides a useful corrective to some recent work in archaeology, whether in relation to materiality, personhood or sociality, that emphasises networks and flows at the expense of commitment and belonging (cf. Bude and Dürrschmidt 2010), requiring us to balance both of these tendencies in an archaeological project based on charting both fixity and fluidity in practice (cf. Gardner 2011; 2013). Furthermore, in emphasising the heterogeneity of bordering processes as well as the specific dynamics of colonial boundaries criss-crossing both territory and person, insights are afforded into the role of frontiers in the imperial societies of antiquity. This again is not a new subject, but is one which is recently undergoing a fresh lease of life, particularly through more in-depth investigation of interactions across frontiers, especially in the Roman world (e.g. Brather 2005; Miller 1996). The extension of this into the realm of colonial subjectivities, in other words the extension of 'border thinking' away from the limes themselves (in the Roman case), seems to be an essential next step in trying to understand such societies. In the first part of this paper, I have tried to construct an argument about the long-term background to Brexit which is in sympathy with the insights of 'border thinking', in terms of the construction of imperial and post-imperial identities in Britain. In the remainder of this paper my aim is to apply them in more detail to a specific window at the beginning of that narrative.

\section{Imperialism, identity and the end of Roman Britain}

An important criterion for the success of a theoretical framework is the extent to which it is scalable. So far I have examined in very broad outline the relationship between 'Britishness' and boundaries in the long-term; here I will explore localised bordering practices to see how they shaped imperial identities in the particular period of the $4^{\text {th }}$ and $5^{\text {th }}$ centuries AD, and thus elucidate the comparability of such processes over time. Some of the recent 'border thinking' work emphasises this scale (Newman 2006: 172-3), and here I focus on the archaeology of what is now north-eastern England in the later Roman period. With limited space to go into detail, I will nonetheless highlight certain archaeological patterns indicating changes in the practices of everyday life which reconfigured social boundaries. I will further argue that these can be seen in terms of the long-term cultural dynamics of empire and 
specifically the opening-up of gaps between localised identities and civic, imperial identities, even among official representatives of the latter. Both levels of identity exhibit a tension between hybridity and essentialism, but over time it seems that the transcendent imperial Roman identity, while increasingly defined from the frontiers, became detached even in such regions from more potent local, 'ethnic' groupings; this clearly has echoes in the fate of 'Britishness' as already discussed. Here I define 'bordering practices' in an expansive sense, building upon some of the work discussed above (esp. Cooper and Perkins 2011; Parker and Vaughan-Williams 2009) to encompass all of the different kinds of activity that people do to create and sustain social boundaries, as well as to cross or erode them - since boundarymaking and boundary-crossing are mutually constitutive. In tandem with a practice-based approach to archaeological materials (cf. Lightfoot et al. 1998; Gardner 2007), this can be highly productive way to look at past social dynamics.

I have discussed elsewhere (Gardner In Press) some of the broad trends apparent in recent archaeological work in northern England and Wales, the regions which comprise the traditional frontier zones of Roman Britain, and in a forthcoming book I am extending the sort of approach discussed here more widely across Britain and Ireland (Gardner In Prep). Here, there is only space to focus on one area where recent publications shed light on changes in practices at the site level over time, which is the stretch of Dere Street in the region of the Tees and Wear valleys, and some of the surrounding landscape (Fig. 2). This locale is convenient for current purposes not so much because it is relatively close to Hadrian's Wall (a day or so's journey to the north), in the 'military zone' of Roman Britain, but rather because of the mixture of different site types with high-quality new excavation and/or publication of earlier work, including forts and rural sites; David Petts has also recently synthesised much of this work in a highly relevant discussion (2013a). This region provides good evidence for the establishment of Roman occupation and the creation of new social boundaries in the $2^{\text {nd }}$ century $\mathrm{AD}$, particularly in comparison with areas to the north of Hadrian's Wall (Hodgson et al. 2012). What I wish to focus on here, though, is the evidence for the reconfiguring of social boundaries at small scales in the later Roman/early postRoman period, and how this might relate to the tensions between broad imperial identities and more local, ethnic ones, as discussed above. Three of the fortified locations on Dere Street are particularly interesting in this regard: Piercebridge (Cool and Mason 2008), Binchester (Ferris 2010), and Catterick (Wilson 2002). Each of these forts separately gives evidence, that can also be found at other military sites across the north and indeed elsewhere in Britain (Gardner 2007: 166-86, 224-9; cf. Collins 2012: 74-110) of two key archaeological trends which relate to bordering practices in the later $4^{\text {th }}$ and early $5^{\text {th }}$ centuries.

One of these trends has to do with the maintenance and even reinforcement of defences, which often stands out amidst limited evidence for new structural work in later Roman forts. This is evident at Piercebridge, where there are signs that the later $3^{\text {rd }}$-century gate within the excavated area (the east gate) was narrowed, and a ditch dug beyond it, at a late $4^{\text {th }}$ or early $5^{\text {th }}$ century date (Cool and Mason 2008: 302-12); similar evidence has been noted at several other northern forts (Collins 2012: 81-88). By way of contrast, the second trend concerns the uses of spaces in the interior of forts, and potentially the breaking down of boundaries. Here, Binchester has an important sequence of evidence suggesting that the predictable hierarchical organisation of the garrison unit, as reflected in the parts of the commanding officer's house which have been excavated, were very pronounced even up until around the end of the $4^{\text {th }}$ century, before parts of the complex were turned over to rubbishdumping, smithing and animal-penning (Ferris 2010: 551-60). This, along with similar evidence from a barrack in the fort's eastern corner, has persuasively been described by Petts (2013a: 319-22, 330) as an indication of social 'convergence' among previously-divided people, and he rightly points out that this might apply across a number of locations with 
similar kinds of evidence for the turning over of previously segregated spaces to rubbishdisposal in the late $4^{\text {th }}$ century (cf. Gardner 2007: 172-83). As a significant part of the activity evidenced here seems to relate to animal management and butchery, this could also indicate that local dependencies were negotiated through communal activities like feasting, rather than official roles and statuses (cf. White 2007: 163-4). Local rural sites provide some important context for these changes, though while several more are known than used to be the case, particularly of the more elaborate 'villa' type that was thought to be very rare in the north, their numbers are still insufficient to generalise (cf. Allen et al. 2015). One key farmstead, at Faverdale, flourishes earlier than the period of focus here, seemingly a high-status site with evidence for a good deal of colonial hybridity in the $2^{\text {nd }}$ century, but with a reduced level of activity, and more regional material culture, in the $4^{\text {th }}$ (Proctor 2012: 165-77). The 'villa' at Ingleby Barwick, by contrast, has some indications that it was home to high-status individual(s), perhaps with military connections, in the late $4^{\text {th }}$ century, and added some imported material culture to its regional suite, evident for example in the pottery assemblage (Petts 2013b; Petts 2013a: 325-8). Such connections between 'military' and 'civilian' sites, to the extent that they are difficult to distinguish materially, are characteristic of the period, and evidence from Catterick for overlaps between the 'fort' and 'town' parts of this site (Wilson 2002: 458-75) fits the picture too.

This picture, then, comprises evidence for new forms of boundary-making and boundary-crossing within an imperial frontier zone. This zone has evidence for the gradual transformation of novel - but already hybridised (cf. Dench 2005) - 'Roman' imperial identities into more locally-rooted hybrids which - as most of these sites have sequences going well beyond the end of Roman administration at the beginning of the $5^{\text {th }}$ century seem to hold the potential to form the basis of post-colonial identities. Fortified places remained important in this landscape (Ferris 2010: 566-70; Petts 2013a: 322-9), but simultaneously appear to have become more fully socially integrated with that landscape than hitherto. Some such links may even extend beyond the line of Hadrian's Wall (Hunter 2010). Whether such patterns fully provided the resources for a 'British', as opposed to regional, identity is difficult to judge, partly because few artefact types survive the economic changes following on from Roman administrative withdrawal, and partly because our later 'British' written sources do not clearly articulate this identity in material terms, but rather in terms of Christianity vis-à-vis the pagan Saxons, and indeed the role of the church in social relations at this time is probably very significant (Higham 2002: 59-72). However, it is ironic - but quite telling - that these Christian writers do not associate their religious identity with 'Romanness'. Overall, therefore, the trajectory of a gradually-developing imbalance between a fragile imperial identity and a localised alternative, which seems to tip toward the latter in a short time, seems clear. One interesting question is whether this process is a cause or a symptom of imperial 'collapse'. In Britain, the cessation of imperial administration, partly prompted by local revolts according to some of the written sources (Dark 1994: 58), comes in the first decade or so of the $5^{\text {th }}$ century, just after these archaeological phenomena become really evident. Yet it seems likely that many features of the late Roman state, from increasing bureaucracy to more centralising ideologies - evident in law-codes and imperial art - are responses to centrifugal forces in the frontier provinces developing from the later $3^{\text {rd }}$ century onwards (see e.g. Miller 1996; cf. Gardner 2007: 247-61). This might be paralleled by the increased state attention to 'Britishness' in the later $19^{\text {th }}$ and early $20^{\text {th }}$ centuries, at the time of greatest pressure on that notion. Moreover, if the development of distinctive frontier cultures which gradually transform the 'core' is a feature of at least the British and Roman empires, then we can also suggest that empires tend to precisely create the circumstances of their own fragmentation, and that - as Brexit shows - the 'core' is not immune to any of 
these effects. Exploring the wider significance of this provides a final note on which to conclude this paper.

\section{Conclusions: the ironies of empire}

Comparison between the post-imperial British context of Brexit and the situation in late Roman Britain is not a perfectly symmetrical exercise. One problem is that, as outlined in the section dealing with the long-term history of 'Britishness', these are causally-connected rather than independent comparanda. Clearly, I have also focussed on Britain throughout when an equally apt comparison to post-imperial (modern) Britain might be post-imperial (Roman) Italy. There are other challenges, too, with the enterprise of imperial comparisons (cf. Hingley 2000; Vasunia 2011), which themselves have a chequered history. I hope, though, to have shown in the intertwined cases discussed here some of the complexity of the processes of imperial and post-colonial or post-imperial identity formation. The basic principles at work here are actually easy to state: like all identity processes, the formation of identities involves dialogue between similarity and difference, and between labels and practices (Jenkins 2014). In imperial contexts, though, the frequently simultaneous construction of hybrid practices and identities alongside supposedly 'pure' cultural ideas of self and other, which buttress more essentialist identities, is shaped in complex ways by dynamics of power and inequality, and the threat or perpetration of violence (cf. Mezzadra and Neilson 2013: viii, 14-5). These are part-and-parcel of the process of imperialism itself, from conquest and expansion, through to fragmentation, collapse, and the formation of new political entities in the aftermath of empire - crucially both in the colonies and the colonizing 'core'. While imperial frontiers produce hybrid formations which in turn shape 'imperial' identities, they also form new ethnicities in those locations; meanwhile, the 'imperial' identity, in ceasing to correspond to other identities at the 'core', begets new (or renewed) ethnic divisions there too (Kearney 1991: 62, 69). Recognising this sort of process is not only significant for archaeologies of empires, but hopefully offers something of more contemporary significance too.

The deep history of bordering practices, subaltern subjectivities, and the transformations of imperial identities over time help us, I would argue, to understand some of what is currently happening in the world today in terms of identity politics, and Brexit provides a clear illustration of this, as I hope to have shown. Here it is appropriate to return to the intersection of the personal, the political and the academic. Of course this is an everpresent balance that we all try to sustain; our interests and politics shape our work, but generally we also strive for inter-subjective, if not objective, coherence. I have written this paper in part as therapy for a traumatic event, because that is how I view the vote to leave the EU. I think that the EU represents a way of moving forward politically that might break the cycle of nationalist and imperial projects which have dominated European history. While it has its weaknesses as an institution, particularly in relation to finding a humane 'frontier policy' at the present moment (Hingley In Prep; cf. Pluciennik 1998), I believe it has done, and can do, more good than harm. I also believe that throwing up barriers does more harm than good. But that is why in this paper I have sought to better understand the processes by which boundaries do get re-made, in the hope that this can inform future debate, which is an academic as well as a personal response. Moreover, uncovering some of the paradoxes of identity-processes sheds some light on the seemingly puzzling ironies of a situation like Brexit. The circumstances which many English and Welsh people seem unhappy about immigration, the export of manufacturing jobs and so on - are consequences of the existence of the British empire; some former colonies - in the British Isles and overseas - have forged a stronger sense of identity than the centre; and 'Britishness' has now again the potential to be a successful hybrid identity favoured by more of the young voters who are also 
enthusiastic about the EU. Identity politics is riven with complexity and contradiction, and its past tense no less so. If the referendum vote tells us anything about the direction of travel, we will need to work hard to defend a nuanced perspective on such matters in an increasingly polarised and reductive climate.

\section{Acknowledgements}

Many thanks to the editor and referees for their comments. I am very grateful to Kathryn Piquette for reading a draft of this paper, and particularly for pointing out the role of diaspora communities in the US and elsewhere in reinforcing certain non-English identities. I would also like to thank Richard Hingley for discussion on the topic and sending me his in-prep paper, and many colleagues at the UCL Institute of Archaeology, including Manuel ArroyoKalin, Chiara Bonacchi, Tina Paphitis, Andrew Reynolds and Matt Pope, for conversations on related themes.

\section{References}

Alibhai-Brown, Y. (2016) Exotic England: The Making of a Curious Nation. London: Portobello Books.

Allen, M., N. Blick, T. Brindle, T. Evans, M. Fulford, N. Holbrook, J.D. Richards and A. Smith (2015) The Rural Settlement of Roman Britain: An Online Resource. http://archaeologydataservice.ac.uk/archives/view/romangl/. Accessed 7/9/16.

Alvarez, R.R. (1995) 'The Mexican-US Border: The Making of An Anthropology of Borderlands'. Annual Review of Anthropology 24: 447-470.

Andrews, K. (2016) 'Colonia Nostalgia is Back in Fashion, Blinding us to the Horrors of Empire'. The Guardian, 24 August 2016. https://www.theguardian.com/ commentisfree/2016/aug/24/colonial-nostalgia-horrors-of-empire-britain-olympic? CMP=twt_gu. Accessed 31/8/16.

Arnold, B. (1990) 'The Past as Propaganda: Totalitarian Archaeology in Nazi Germany'. Antiquity 64: 464-478.

Atkinson, J.A., I. Banks and J. O’Sullivan (eds) (1996) Nationalism and Archaeology. Glasgow: Cruithne Press.

Barnett, S. (2016) 'The Tragic Downfall of British Media'. 8 July 2016. Foreign Policy, http://foreignpolicy.com/2016/07/08/the-tragic-downfall-of-british-media-tabloidsbrexit/. Accessed 23/8/16.

BBC (2013) Night Waves: Englishness. Broadcast 24 April 2013, BBC Radio 3. http://www.bbc.co.uk/programmes/b01ryv0s. Accessed 23/8/16.

BBC (2014a) 'Scottish Referendum: Scotland Votes 'No' to Independence'. 19 September 2014. http://www.bbc.co.uk/news/uk-scotland-29270441. Accessed 19/8/16.

BBC (2014b) “'British' Wales Star Sam Warburton Sparks Political Row'. 7 March 2014. http://www.bbc.co.uk/news/uk-wales-26472782. Accessed 31/8/16.

BBC (2015) 'Timeline: Campaigns for a European Union Referendum'. 21 May 2015. http://www.bbc.co.uk/news/uk-politics-15390884. Accessed 19/8/16.

BBC (2016a) 'EU Referendum Timeline: Countdown to the Vote'. 20 February 2016. http://www.bbc.co.uk/news/uk-politics-33141819. Accessed 19/8/16.

BBC (2016b) 'EU Referendum Results'. 24 June 2016. http://www.bbc.co.uk/news/politics/eu_referendum/results. Accessed 19/8/16.

BBC (2016c) 'Brexit Britain: What has actually happened so far?'. 24 November 2016. http://www.bbc.co.uk/news/business-36956418. Accessed 1/12/16.

BBC (2016d) ' English Votes' Rules Used for First Time in House of Commons'. 12 January 2016. http://www.bbc.co.uk/news/uk-politics-35295404. Accessed 23/8/16. 
BBC (2016e) 'EU Referendum: the Result in Maps and Charts'. 24 June 2016. http://www.bbc.co.uk/news/uk-politics-36616028. Accessed 23/8/16.

Brather, S. (2005) 'Acculturation and Ethnogenesis Along the Frontier: Rome and the Ancient Germans in an Archaeological Perspective'. In F. Curta (ed.) Borders, Barriers and Ethnogenesis: Frontiers in Late Antiquity and the Middle Ages, pp. 139171. Turnhout: Brepols.

Bude, H. and J. Dürrschmidt (2010) 'What's Wrong with Globalization?: Contra 'Flow Speak' - Towards an Existential Turn in the Theory of Globalization'. European Journal of Social Theory 13(4), 481-500.

Casella, E.C. and C. Fowler (2005) 'Beyond Identification: An Introduction'. In E.C. Casella and C. Fowler (eds) The Archaeology of Plural and Changing Identities: Beyond Identification, pp. 1-8. New York: Kluwer/Plenum.

Colley, L. (1992) 'Britishness and Otherness: An Argument'. Journal of British Studies 31(4): 309-329.

Colley, L. (2007) 'Does Britishness Still Matter in the $21^{\text {st }}$ Century - and How Much and How Well do the Politicians Care?' Political Quarterly 78: 21-31.

Collins, R. (2012) Hadrian's Wall and the End of Empire. London: Routledge.

Collis, J. (2003) The Celts: Origins, Myths and Inventions. Stroud: Tempus.

Colls, R. (2002) Identity of England. Oxford: O.U.P.

Colwell-Chanthaphonh, C. (2012) 'Archaeology and Indigenous Collaboration'. In I. Hodder (ed.) Archaeological Theory Today ( $2^{\text {nd }}$ edition), pp. 267-291. Cambridge: Polity.

Cool, H.E.M. and D.J.P. Mason (2008). Roman Peircebridge: Excavations by D.W. Harding and Peter Scott 1969-1981. Durham: AASDN.

Cooper, A. and C. Perkins (2011) 'Borders and Status-Functions: An Institutional Approach to the Study of Borders'. European Journal of Social Theory 15(1), 55-71.

Creighton, J. (2000) Coins and Power in Late Iron Age Britain. Cambridge: C.U.P.

Cusick, J.G. (ed.) (1998) Studies in Culture Contact: Interaction, Culture Change, and Archaeology. Carbondale: Southern Illinois University.

Dark, K.R. (1994) Civitas to Kingdom: British Political Continuity 300-800. Leicester: Leicester University Press.

Davies, R.R. (2000) The First English Empire: Power and Identities in the British Isles 10931343. Oxford: O.U.P.

Dench, E. (2005) Romulus' Asylum: Roman Identities from the Age of Alexander to the Age of Hadrian. Oxford: O.U.P.

Derks, T. and N. Roymans (2009) 'Introduction.' In T. Derks and N. Roymans (eds) Ethnic Constructs in Antiquity, pp. 1-10. Amsterdam: Amsterdam University Press

Díaz-Andreu, M. (2007) A World-History of Nineteenth Century Archaeology: nationalism, colonialism, and the past. Oxford: O.U.P.

Díaz-Andreu, M., S. Lucy, S. Babić and D.N. Edwards (eds) (2005) The Archaeology of Identity. London: Routledge.

Easton, M. (2013) 'How British is Britain?' 30 September 2013. http://www.bbc.co.uk/news/uk-24302914. Accessed 31/8/16.

Edmunds, J. (2004) 'Redefining Britannia: The Role of 'Marginal' Generations in Reshaping British National Consciousness'. In H. Brocklehurst and R. Phillips (eds) History, Nationhood and the Question of Britain, pp. 73-84. Basingstoke: Palgrave Macmillan.

Electoral Commission (2016) 'Guidance for Campaigners for the Referendum on the United Kingdom's Membership of the European Union.' http://www.electoralcommission.org.uk/i-am-a/party-or-campaigner/campaigners-inreferendums. Accessed 19/8/16. 
Ferguson, R.B. and N.L. Whitehead (eds.) (2000) War in the Tribal Zone: Expanding States and Indigenous Warfare (2nd edition). Santa Fe: School of American Research Press / Oxford: James Currey.

Ferris, I. (2010) The Beautiful Rooms are Empty: Excavations at Binchester Roman Fort, County Durham 1976-1981 and 1986-1991. Durham: Durham County Council.

Flip Chart Fairy Tales (2016) 'Looking Behind the Brexit Anger'. 28 June 2016. https://flipchartfairytales.wordpress.com/2016/06/28/looking-behind-the-brexitanger/. Accessed 23/8/16.

Gardner, A. (2007) An Archaeology of Identity: Soldiers and Society in Late Roman Britain. Walnut Creek: Left Coast Press.

Gardner, A. (2011) 'Paradox and Praxis in the Archaeology of Identity'. In L. AmundsenMeyer, N. Engel and S. Pickering (eds.) Identity Crisis: Archaeological Perspectives on Social Identity. Proceedings of the 42nd (2009) Chacmool Conference, pp. 11-26. Calgary: Chacmool Archaeology Association.

Gardner, A. (2013) 'Thinking About Roman Imperialism: Postcolonialism, Globalization and Beyond?'. Britannia 44: 1-25.

Gardner, A. (In Press) 'Roman Britain from the Outside: Comparing Western and Northern Frontier Cultures'. In S. González Sánchez and A. Guglielmi (eds.) 'Romans' and 'Barbarians' Beyond the Frontiers: Archaeology, Ideology and Identities in the North. Oxford: Oxbow Books (TRAC Research Papers).

Gardner, A. (In Prep) Roman Britain, 55BC-AD450. London: Palgrave Macmillan.

Gardner, A., E. Herring and K. Lomas (eds) (2013) Creating Ethnicities and Identities in the Roman World. London: Institute of Classical Studies.

Geary, P.J. (2002) The Myth of Nations: The Medieval Origins of Europe. Princeton: Princeton University Press.

Gill, J. (2016) 'Leader: Digesting a Shock to the System'. Times Higher Education, 30 June 2016 (No. 2261): 5.

Given, M. (2004) The Archaeology of the Colonized. London: Routledge.

Goffman, E. (1990 [1959]) The Presentation of Self in Everyday Life. London: Penguin.

Gosden, C. (2012) 'Postcolonial Archaeology'. In I. Hodder (ed.) Archaeological Theory Today ( $2^{\text {nd }}$ edition), pp. 251-266. Cambridge: Polity Press.

Green, S. (ed.) (2016) 'Brexit Referendum: First Reactions from Anthropology'. Social Anthropology 24(4): 478-502.

Gustafsson, A. and H. Karlsson (2011) 'A Spectre is Haunting Swedish Archaeology - the Spectre of Politics. Archaeology, Cultural Heritage and the Present Political Situation in Sweden'. Current Swedish Archaeology 19: 11-36.

Hales, S. and T. Hodos (eds) (2010) Material Culture and Social Identities in the Ancient World. Cambridge: C.U.P.

Hall, C. (2008) 'Culture and Identity in Imperial Britain'. In S. Stockwell (ed.) The British Empire: Themes and Perspectives, pp. 199-217. Oxford: Blackwell.

Harris, O. (2016) 'Becoming Post-Human: Identity and the Ontological Turn'. In E. Pierce, A. Russell, A. Maldonado and L. Campbell (eds) Creating Material Worlds: The Uses of Identity in Archaeology, pp. 17-37. Oxford: Oxbow Books.

Hechter, M. (1975) Internal Colonialism: The Celtic Fringe in British National Development, 1536-1966. London: Routledge \& Kegan Paul.

Higham, N.J. (2002) King Arthur: Myth-making and History. London: Routledge.

Hill, J.D. (2007) 'The Dynamics of Social Change in Later Iron Age Eastern and SouthEastern England c.300 BC - AD 43'. In C. Haselgrove and T. Moore (eds) The Later Iron Age in Britain and Beyond, pp. 16-40. Oxford: Oxbow Books.

Hills, C. (2003) Origins of the English. London: Duckworth. 
Hills, C. (2011) 'Overview: Anglo-Saxon Identity'. In D.A. Hinton, S. Crawford and H. Hamerow (eds) The Oxford Handbook of Anglo-Saxon Archaeology, pp. 3-12. Oxford: O.U.P.

Hingley, R. (2000) Roman Officers and English Gentlemen: the Imperial Origins of Roman Archaeology. London: Routledge.

Hingley, R. (2015) 'Working with Descendent Communities in the Study of Roman Britain: Fragments of an Ethnographic Project Design'. In C.N. Cipolla and K.H. Hayes (eds) Rethinking Colonialism: Comparative Archaeological Approaches, pp. 161-189. Gainesville: University Press of Florida.

Hingley, R. (In Prep) 'European Borders and the Roman Empire: Linking Disciplinary Fields'. European Journal of Archaeology.

Hodgson, N., J. McKelvey and W. Muncaster (2012) The Iron Age on the Northumberland Coastal Plain. Newcastle: TWM Archaeology / Arbeia Society.

Hunter, F. (2007) Beyond the Edge of the Empire: Caledonians, Picts and Romans. Rosemarkie: Groam House Museum.

Hunter, F. (2010) 'Beyond the Frontier: Interpreting Late Roman Iron Age Indigenous and Imported Material Culture. In R. Collins and L. Allason-Jones (eds.) Finds from the Frontier: Material Culture in the $4^{\text {th }}-5^{\text {th }}$ Centuries, pp. 96-109. York: CBA (Research Report 162).

Ichijo, A. (2004) 'Civic or Ethnic? The Evolution of Britishness and Scottishness'. In H. Brocklehurst and R. Phillips (eds) History, Nationhood and the Question of Britain, pp. 112-123. Basingstoke: Palgrave Macmillan.

James, S. (1999) The Atlantic Celts: Ancient People or Modern Invention? London: British Museum Press.

Jones, S. (1997) The Archaeology of Ethnicity. London: Routledge.

Jenkins, R. (2000) 'Categorization: Identity, Social Process and Epistemology'. Current Sociology 48(3): 7-25.

Jenkins, R. (2014) Social Identity (4 ${ }^{\text {th }}$ edition). London: Routledge.

Jenkins, R. (2015) 'Boundaries and Borders'. In J. Jackson and L. Molokotos-Liederman (eds) Nationalism, Ethnicity and Boundaries, pp. 11-27. London: Routledge.

Jones, M.E. (1996) The End of Roman Britain. Ithaca: Cornell University Press.

Kearney, M. (1991) 'Borders and Boundaries of State and Self at the End of Empire'. Journal of Historical Sociology 4(1): 52-74.

Kidd, C. (1999) British Identities Before Nationalism: Ethnicity and Nationhood in the Atlantic World, 1600-1800. Cambridge: C.U.P.

Kohl, P.L. and C. Fawcett (eds) (1995) Nationalism, Politics, and the Practice of Archaeology. Cambridge: C.U.P.

Kolossov, V. (2005) 'Border Studies: Changing Perspectives and Theoretical Approaches'. Geopolitics 10(4): 606-632.

Krishnaswamy, R. (2007) 'Postcolonial and Globalization Studies: Connections, Conflicts, Complicities'. In R. Krishnaswamy and J.C. Hawley (eds) The Postcolonial and the Global, pp. 2-21. Minneapolis: University of Minnesota Press.

Lawrence, S. (2003) 'Introduction: Archaeological Perspectives on the British and their Empire'. In S. Lawrence (ed.) Archaeologies of the British: Explorations of Identity in Great Britain and its Colonies 1600-1945, pp. 1-13. London: Routledge.

Lightfoot, K.G. and A. Martinez (1995) 'Frontiers and Boundaries in Archaeological Perspective.' Annual Review of Anthropology 24: 471-492.

Lightfoot. K.G., A. Martinez, and A.M. Schiff (1998) 'Daily Practice and Material Culture in Pluralistic Social Settings: An Archaeological Study of Culture Change and Persistence from Fort Ross, California.' American Antiquity 63(2): 199-222. 
Madood, T. (2004) 'Britishness Out of Immigration and Anti-Racism'. In H. Brocklehurst and R. Phillips (eds) History, Nationhood and the Question of Britain, pp. 85-98. Basingstoke: Palgrave Macmillan.

Martinson, J. (2016) 'Did the Mail and Sun help swing the UK towards Brexit?'. The Guardian, 24 June 2016, https://www.theguardian.com/media/2016/jun/24/mail-sunuk-brexit-newspapers. Accessed 31/8/16.

Matthews, K.J. (1999) 'Britannus/Britto: Roman Ethnographies, Native Identities, Labels, and Folk Devils'. In A. Leslie (ed.) Theoretical Roman Archaeology and Architecture (the Third Conference Proceedings), pp. 14-32. Glasgow: Cruithne Press.

Mattingly, D. (2004) 'Being Roman: Expressing Identity in a Provincial Setting'. Journal of Roman Archaeology 17: 5-25.

Mattingly, D. (2006) An Imperial Possession: Britain in the Roman Empire, 54BC - AD409. London: Penguin.

McGuire, R. (2008) Archaeology as Political Action. Berkeley: University of California Press.

Meskell, L. (ed.) (1998) Archaeology Under Fire. London: Routledge.

Meskell, L. (1999) Archaeologies of Social Life: Age, Sex, Class etc. in Ancient Egypt. Oxford: Blackwell.

Meskell, L. (2001) 'Archaeologies of Identity'. In I. Hodder (ed.) Archaeological Theory Today ( $1^{\text {st }}$ edition), pp. 187-213. Cambridge: Polity Press.

Meskell, L. (2002) 'The Intersections of Identity and Politics in Archaeology'. Annual Review of Anthropology 31: 279-301.

Mezzadra, S. and B. Neilson (2013) Border as Method, or, the Multiplication of Labor. Durham: Duke University Press.

Miller, D.H. (1996) 'Frontier Societies and the Transition Between Late Antiquity and the Early Middle Ages'. In R.W. Mathisen and H.S. Swan (eds) Shifting Frontiers in Late Antiquity, pp. 158-171. Aldershot: Variorum.

Mignolo, W.D. and M.V. Tlostanova (2006) 'Theorizing from the Borders: Shifting to Geoand Body-Politics of Knowledge'. European Journal of Social Theory 9(2): 205-221.

Moore, T. (2011) 'Detribalizing the Later Prehistoric Past: Concepts of Tribes in Iron Age and Roman Studies'. Journal of Social Archaeology 11(3): 334-360.

Newman, D. (2006) 'Borders and Bordering: Towards an Interdisciplinary Dialogue'. European Journal of Social Theory 9(2): 171-186.

Paphitis, T. (2014) The Place of Folklore in Archaeological Landscapes: Narratives and Identity in Medieval to Modern Britain. PhD Thesis, University College London.

Parker, N. and N. Vaughan-Williams (2009) 'Lines in the Sand? Towards an Agenda for Critical Border Studies'. Geopolitics 14: 582-587.

Parliament (2015) 'European Union Referendum Act 2015'. 17 December 2015. http://services.parliament.uk/bills/2015-16/europeanunionreferendum.html. Accessed $19 / 8 / 16$.

Parry, M. (2016) 'Uncovering the Brutal Truth About the British Empire'. The Guardian, 18 August 2016. https://www.theguardian.com/news/2016/aug/18/uncovering-truthbritish-empire-caroline-elkins-mau-mau. Accessed 31/8/16.

Petts, D. (2013a) 'Military and Civilian: Reconfiguring the End of Roman Britain in the North'. European Journal of Archaeology 16:2, 314-335.

Petts, D. (2013b) 'Late Roman to Early Medieval Settlement at Ingleby Barwick: Discussion'. In S. Willis and P. Carne (eds) A Roman Villa at the Edge of Empire: Excavations at Ingleby Barwick, Stockton-on-Tees, 2003-4, pp. 195-199. York: CBA.

Pitts, M. (2007) 'The Emperor's New Clothes? The Utility of Identity in Roman Archaeology'. American Journal of Archaeology 111: 693-713. 
Pluciennik, M. (1998) 'Archaeology, Archaeologists and 'Europe'. Antiquity 72(278): 816824.

Porter, B. (2004) 'Empire and British National Identity, 1815-1914'. In H. Brocklehurst and R. Phillips (eds) History, Nationhood and the Question of Britain, pp. 259-273. Basingstoke: Palgrave Macmillan.

Proctor, J. (2012) Faverdale, Darlington: Excavations at a Major Settlement in the Northern Frontier Zone of Roman Britain. London: Pre-Construct Archaeology.

Preston, P.W. (2004) Relocating England: Englishness in the New Europe. Manchester: Manchester University Press.

Rumford, C. (2006) 'Introduction: Theorizing Borders'. European Journal of Social Theory 9(2): 155-169.

Shennan, S.J. (ed.) (1989) Archaeological Approaches to Cultural Identity. London: Routledge.

Stark, M.T. (ed.) (1998) The Archaeology of Social Boundaries. Washington: Smithsonian.

Stein, G.J. (ed.) (2005) The Archaeology of Colonial Encounters: Comparative Perspectives. Santa Fe: School of American Research Press.

Taylor, B. (2016) 'Brexit - a story in maps'. 11 August 2016. https://medium.com/@jakeybob/brexit-maps-d70caab7315e\#.t825itls2. Accessed 23/8/16.

Tilley, C. (1989) 'Archaeology as Socio-political Action in the Present'. In V. Pinsky and A. Wylie (eds) Critical Traditions in Contemporary Archaeology, pp. 104-116. Cambridge: C.U.P.

Trigger, B. (1984) 'Alternative Archaeologies: Nationalist, Colonialist, Imperialist'. Man 19: 355-370.

Trevor-Roper, H. (1983) 'The Invention of Tradition: The Highland Tradition of Scotland'. In E. Hobsbawm and T. Ranger (eds) The Invention of Tradition, pp. 15-42. Cambridge: C.U.P.

Vasunia, P. (2011) 'The Comparative Study of Empires'. Journal of Roman Studies 101: 222237.

Ward, S. (2004) 'The End of Empire and the Fate of Britishness'. In H. Brocklehurst and R. Phillips (eds) History, Nationhood and the Question of Britain, pp. 242-258. Basingstoke: Palgrave Macmillan.

White, R. (2007) Britannia Prima: Britain's Last Roman Province. Stroud: Tempus.

Williams, H. (2016) 'The Trump Wall in Archaeological Perspective'. November 142016. https://howardwilliamsblog.wordpress.com/2016/11/14/the-trump-wall-inarchaeological-perspective/. Accessed 1/12/16.

Wilson, P.R. (2002) Cataractonium: Roman Catterick and its Hinterland. Excavations and Research, 1958-1997 (Part II). York: CBA (Research Report 129).

Wilson S. (2014) 'Britain and the EU: A Long and Rocky Relationship'. 1 April 2014. http://www.bbc.co.uk/news/uk-politics-26515129. Accessed 19/8/16.

Yeandle, P. (2004) 'Lessons in Englishness and Empire, c.1880-1914: Further Thoughts on the English/British Conundrum. In H. Brocklehurst and R. Phillips (eds) History, Nationhood and the Question of Britain, pp. 274-286. Basingstoke: Palgrave Macmillan.

Young, R.J.C. (2008) The Idea of English Ethnicity. Oxford: Blackwell. 


\section{Figure Captions}

Fig. 1: Data from the 2011 census for England, with darker shades showing higher percentages of 'English' identification (a), and the referendum results (b) (James Trimble \& http://ukdataexplorer.com/census/england/; Taylor 2016; both with permission).

Fig. 2: Location map of sites mentioned in the text, with other key sites and the line of Hadrian's Wall marked (Digital Atlas of the Roman Empire [http://dare.ht.lu.se/], under Creative Commons BY-SA 3.0 Licence, with permission, and with additions). 


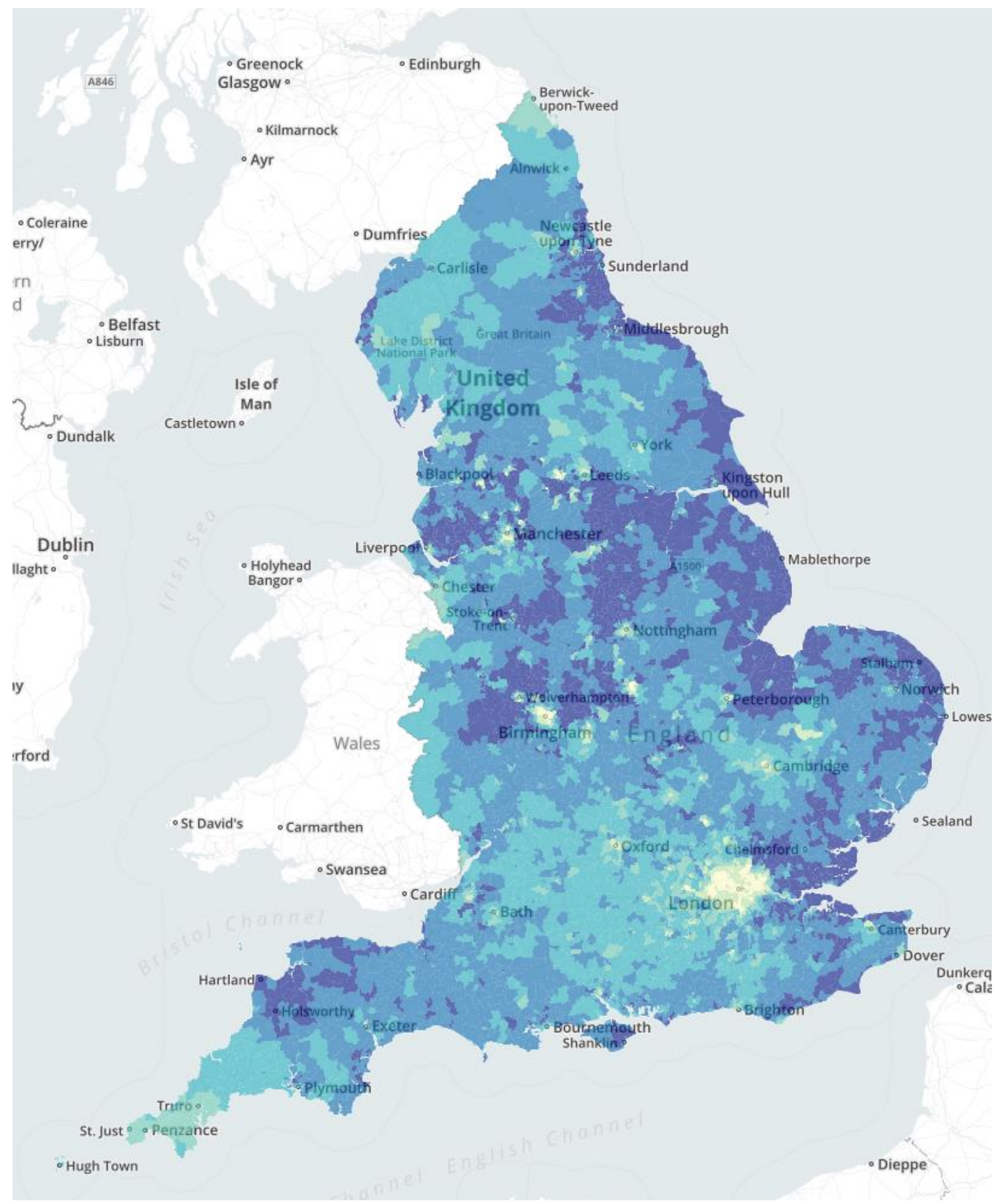




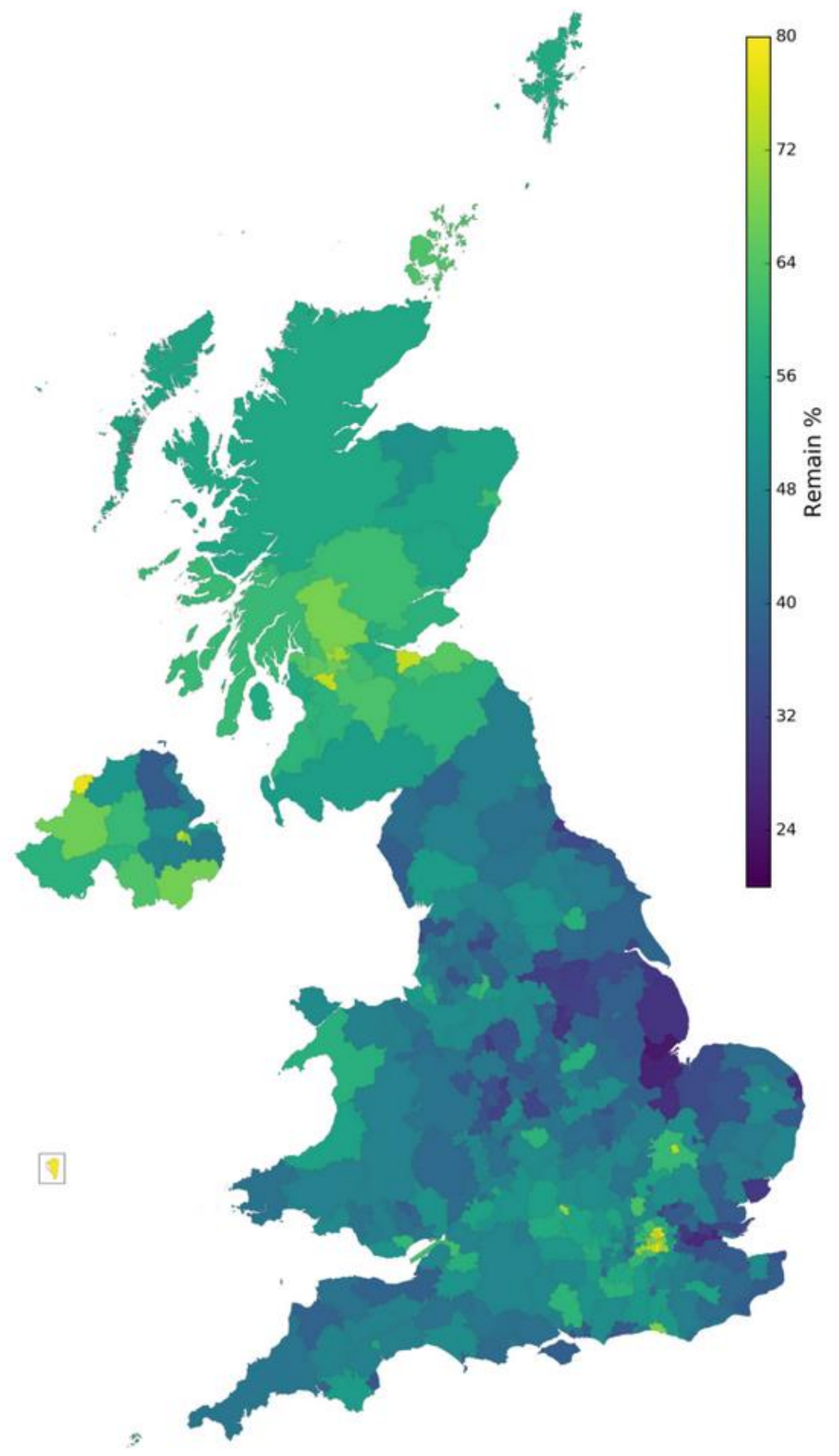




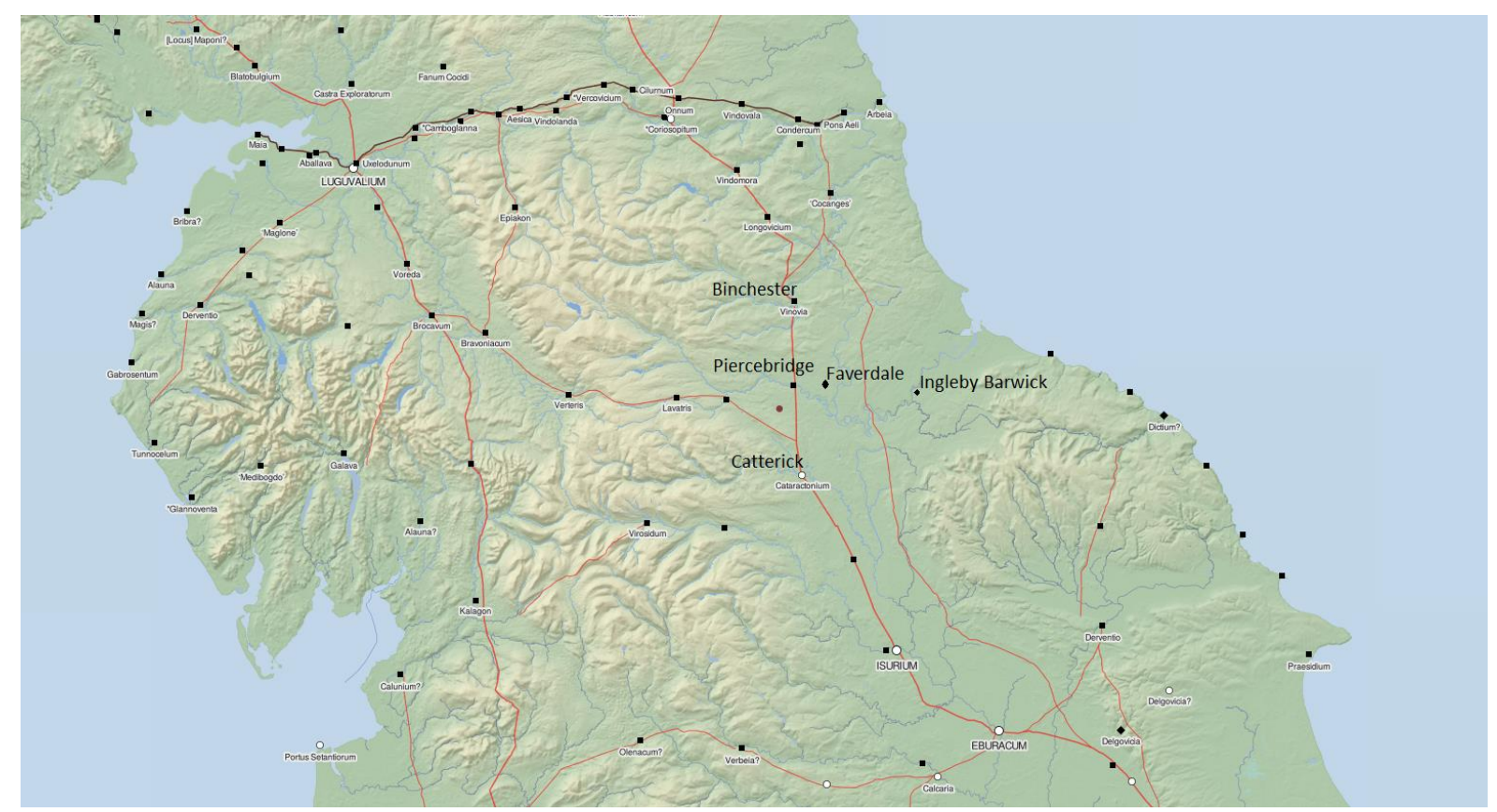

